CHAPTER 12

\title{
Moral structure
}

\section{George Corbett}

The epistle to Cangrande, purportedly written by Dante towards the end of his life as a commentary on his poem, classifies the Commedia as 'a work of ethics': its purpose is to lead people from the misery of sin and to direct them to the beatitude of Heaven (XIII, 15-16). In the poem itself, Beatrice commands Dante-character to write 'for the good of the world which lives badly' (in pro del mondo che mal vive; Purg. XXXII, 103). The Commedia is thus 'vital nourishment' (vital nodrimento; Par. XVII, 131) because, by depicting the state of souls in the three realms of the medieval Christian afterlife, it shows how a person - through the use of free will - may merit eternal happiness in Paradise, eternal damnation in Hell, or require temporary expiation for sin in Purgatory (Ep. XIII, 11). Dante projects these three realms onto the contemporary geocentric world view (the earth as the centre of the cosmos), creatively joining his original moral vision to the macro-history of salvation. Dante imagines that when Satan fell from Heaven, the earth in the northern hemisphere recoiled in horror, creating the spiralling funnel of Hell. This displaced mass of earth then formed the conical mountain of Purgatory in the southern hemisphere, humanity's way back to God. As the pilgrim descends into Hell, he encounters increasingly grave human evils until he reaches Satan at the earth's exact centre. As he ascends the mountain of Purgatory, he gets ever closer to God and ever further from Satan: the sins he encounters thus decrease in gravity. Likewise, as he ascends through the nine heavenly spheres on his way to the Empyrean, he encounters blessed souls characterized by ever greater virtues and ever greater holiness. In short, the poem follows the simple, moral-geographical law that to rise up is good, to sink down is bad.

However, Dante's moral vision is especially innovative for its detailed and systematic ordering of saints and sinners. At a fundamental level, the number symbolism of three (the Trinity) and nine (creation) underpins the poem's moral structure. There are nine circles of Hell and, with the notable exceptions of circles one and six, there are three main categories of evil: incontinence (circles 2-5), violence (circle 7), and fraud (circles 8-9). There are nine principal areas of Purgatory: the seven terraces that purify the seven capital vices (pride, envy, wrath, sloth, avarice, gluttony, and lust) are framed by the two regions of Ante-Purgatory and the Earthly Paradise. And there are nine heavens of Paradise, governed by the nine orders of angels. Although the moral structure is less explicit in Paradise, Dante does seem to allude to the three theological virtues (faith, hope, and charity) and the 
four cardinal virtues (prudence, fortitude, justice, and temperance) in the first seven planetary spheres. Furthermore, Dante-character is examined on the three theological virtues in the eighth heaven of the Fixed Stars.

Topographical markers are further delineators of moral structure. These are particularly clear in Purgatory (the seven terraces of the mountain) and in Paradise (the planetary heavens). The moral structure of Hell, however, is particularly complex. Dante divides up its multiple regions and sub-regions through a variety of topographical elements, drawing upon a range of sources from classical texts, such as Virgil's Aeneid and Statius's Thebaid, to Christian voyage and vision literature and preaching manuals. Upper Hell (circles 1-5) is entered through a gateway; Lower Hell (circles 6-9) is within the city of Dis. A steep cliff divides the sins of violence (circle 7) from the ten 'evil ditches' (Malebolge) of simple fraud (circle 8), while a central well sets apart the treacherous (circle 9). Differing landscapes are used to subdivide regions: thus, a bloody river, a thorny wood, and a fiery desert segment the seventh circle of violence into violence against another, against self, and against God. Dante draws especially on Virgil's depiction of the pagan underworld in Aeneid VI, transforming this material in ingenious ways. He borrows four rivers to mark off groups of sinners: Acheron divides the 'neutrals' from the rest of the damned sinners (Inf. III); Styx contains the wrathful and the sullen (VII), Phlegethon the violent against others (XII), the icy lake of Cocytus the treacherous (XXXI). Similarly, Dante transforms mythological monsters to describe or nuance moral structure. For example, Dante gives Virgil's infernal judge Minos a monstrous tail that he grotesquely wraps around himself one to nine times depending on the circle of Hell allotted to a sinner's damnation (V, 4-12).

How original, then, is Dante's moral system, and what might it indicate about his wider political and theological outlook? What criteria does he employ to judge that some sins are worse than others, and conversely that some goods are more valuable than others? How, moreover, does Dante represent the moral structure of his afterlife in the poem? After all, Dante could have started his poem with a 'table of contents' outlining the moral structure of each of the three canticles. But he chose not to, deliberately withholding the kind of bird's eye view provided by later commentators, especially in the Renaissance, and by introductory visual diagrams in modern editions of the poem. It is only a third of the way through Hell (XI), half way through Purgatory (XVII), and two thirds of the way through Paradise (XXII) that we find a gloss on the regions' moral structures. We should be sensitive, therefore, to the way in which Dante progressively builds a moral structure into his poem and to its narrative effects.

\section{Inferno}

One of many interpretations of the three beasts that Dante-character encounters at the beginning of his journey - the leopard, the lion, and the she-wolf (Inf. I, 31-60) - is 
that they represent the basic tripartite moral structure of Dante's Hell: incontinence, violence, and fraud. However, such symbolism is allusive at best, and the actual moral classification of sins occurs only after Dante-character has entered the city of Dis. Without the benefit of scholarly diagrams and maps, the first readers of Dante's poem would have been initially disorientated as surprise builds upon surprise: the pilgrim's first moral guide is not an authoritative Christian saint but the pagan poet Virgil; the first group of sinners encountered, the 'neutrals', are unknown to medieval theology and entirely Dante's own invention (III, 21-69); the first circle of Hell, Limbo, is radically revised by Dante to include virtuous pagans. Given that the second circle is devoted to lust, the third to gluttony, the fourth to avarice and prodigality, and the fifth to wrath, the reader might naturally suppose that the seven deadly sins (or capital vices) is an ordering principle. But Dante sets up this expectation only to frustrate it for the system of the seven deadly sins then decisively breaks down. Although sloth may be implicitly condemned as a counterpart to wrath (VII, 115-26), there is no circle dedicated to either envy or pride despite these two remaining deadly sins being referenced alongside avarice, in Inferno VI, 74. Boccaccio first claimed that the opening of Inferno VIII - 'Continuing, I have to tell' (Io dico seguitando) - represents Dante's return to writing after a decisive break, and some critics suggest that Dante changed his mind about the moral structure of Hell in the process of writing. It has been argued, for example, that Dante originally intended to embody envy in Cavalcante dei Cavalcanti and pride in Farinata, and only later salvaged the material in his masterly creation of the tenth canto of the Epicureans. Dante, of course, ultimately deploys the scheme of the seven vices to structure Purgatory. Whether or not he originally intended the scheme for Upper Hell, its suggestion remains strong, providing interesting points of parallel and contrast with its later development in the second canticle.

The delayed classification of moral evil is presented when the pilgrim and Virgil are unable to descend further because of the horrible stench cast up by the abyss of Lower Hell. They are forced to wait while they become accustomed to it and Virgil makes the time profitable by finally explaining Hell's moral structure (XI, 1666). There is a threefold distinction: first, between incontinence (Upper Hell) and malice (Lower Hell); second, between malice through violence (circle 7) and malice through fraud (circles 8 and 9); and third, between simple fraud like counterfeiting, which deceives a stranger who has no particular reason to trust us (circle 8), and treacherous fraud like betraying one's own father, which deceives someone who has a special reason to trust us, and thus breaks a special bond of love (circle 9). Many scholars have posited an inconsistency in Virgil's rationale that apparently derives from Dante's fusion of two sources. Where Cicero's De officiis, I, 13 subdivides malice into violence and fraud (XI, 22-4), Aristotle's Ethics, VI, 1-6 distinguishes between incontinence, malice, and mad bestiality (79-84). However, Virgil's rationale is arguably consistent. On such an interpretation, the Ciceronian and Aristotelian usages of the term 'malice' (22 and 82) both map onto the region of Lower Hell as a whole; the Ciceronian subdivision between 'violence and fraud' 
differentiates circles seven and eight; the Aristotelian 'mad bestiality' serves as a subcategory of the genus 'malice' to indicate extreme cruelty, thereby differentiating circles eight and nine. In this way, Virgil's rationale effectively demarcates the four main regions of Hell: the four circles of incontinence; the three 'rings' (gironi) of violence; the ten concentric 'pouches' (Malebolge) of simple fraud; and the pit of Cocytus consisting of four sub-circles of treacherous fraud.

The circles of incontinence follow the principle of 'counter-punishment' (contrapasso; Inf. XXVIII, 142) explicitly referenced by the Occitan poet Bertran de Born, according to which infernal suffering reflects the nature of the sin being punished. For Dante, human beings are rational animals: as incontinent sinners subject their reason to their desire (they know what the right moral action is but, despite this, do evil because of an overwhelming passion), they become - in act - like a beast or even like vegetative or inanimate matter. For the lustful sinners stripped of reason, the sensual pleasure of touch, shared by all animals, becomes their overpowering desire, and in Hell, in keeping with medieval bestiary lore, they are consequently compared to birds buffeted by the wind (Inf. V). For the gluttons, bodily nourishment necessary also to plant life becomes their overriding desire. In Hell, they appear human but in reality they have become indistinguishable from beasts and wallow in their own filth like dogs and pigs (Inf. VI). The avaricious make material goods, inanimate matter, their goal and become in Hell little better than the boulders they must endlessly push around (Inf. VII). Finally, according to the extent of their wrath, the sinners in the fifth circle are submerged by degrees in a river of blood (Inf. VIII).

As Virgil clarifies (XI, 28-33), the seventh circle of violence is divided into three rings: violence against one's neighbour (Inf. XII), against oneself (Inf. XIII), and against God (Inf. XIV-XVII). Modern commentators typically trace this triple division to Aquinas but, even if this is his source, Dante uses these categories in a very different way: for example, the classification 'sins against the self' includes, for Aquinas, the intemperate sins of gluttony and lust whereas, for Dante, it is restricted to wilful self-destruction (suicide or a squandering of one's own possessions). More convincing, in my view, is that these three victims of man's violence (neighbour, self, and God) are connected to the parallel victims of man's hatred in Virgil's corresponding lecture on the moral structure of Purgatory (Purg. XVII, 104-14). Virgil explains there that one cannot hate God directly because God is the necessary cause of our existence. One can rebel against God indirectly, however, insofar as our disordered will hates God's effects such as His supremacy or His prohibition of sins. In this way, violence against God is possible. Similarly, we cannot hate ourselves directly but we can do violence to ourselves. Thus, for example, we may misjudge as good in some respect something that is, in fact, evil: the suicide may kill himself in order to end misery and suffering. From Virgil's lecture in Purgatory, therefore, we may understand why violence against self (our very existence) and against God (the origin of that existence) are - for Dante - not only possible but progressively more grave than violence against neighbour (who is outside our existence). Virgil's 
threefold division of violence against God into blasphemy (Inf. XIV), sodomy (Inf. $\mathrm{XV}-\mathrm{XVI}$ ), and usury (Inf. XVII) in the third ring of violence (a sterile desert battered by a rain of fire) requires, however, further comment and, in the narrative, provokes Dante-character's puzzlement (XI, 94-6). Citing Aristotle's Physics and, for further confirmation, the theological authority of Genesis, Virgil argues that Nature takes its course from the Divine Intellect, while human work takes its course from Nature. Where blasphemy scorns God directly, the sexual act of sodomy (whether between two men or between a man and a woman) disdains the principle of fertility in Nature and, consequently, indirectly scorns God. Usury - the lending of money at interest scorns Nature because, as Aristotle argued, it is unnatural that money should beget money (Politics, I, 10). It also derides human work because the creditor does not add value and instead receives something (the interest) for nothing (the original sum of money is returned risk free).

Virgil allots only a single terzina to the ten species of simple fraud (circle 8): 'hypocrisy, flattery, divining, impersonators, theft and simony, panders, barrators, and like filth' (ipocresia, lusinghe e chi affatura, / falsità, ladroneccio e simonia, / ruffian, baratti e simile lordura; XI, 58-60). Virgil's list is in no apparent order, and two sins are missed out entirely. Is this accidental? Is it just for convenience of versification and rhyme? Does Dante, at this point of writing, not have a clear plan of how he will structure Malebolge? Whatever the reason, there is a clear narrative effect: the reader must discover those sins unnamed by Virgil - the counsellors of fraud (eighth bolgia) and the sowers of scandal and schism (ninth bolgia) - and also the respective gravity of the sins enumerated. Moreover, it may be that Dante is more concerned to stress the generic effect of simple fraud, which offends against the natural bond of love between human beings, than its degrees (and it is noticeable that no more detailed rationale is given). In this light, it is striking that half of Dante's Inferno (cantos XVIII-XXXIV) is concerned with the sin of fraud, whether simple (circle 8) or treacherous (circle 9). The moral weighting of Inferno arguably reflects Dante's profound concern with the way in which fraud perverts human reason and its expression through language. As Barański has demonstrated, Dante succeeds in integrating nineteen out of twenty-four of the 'sins of the tongue' listed in Peraldus's thirteenth-century preaching manual De vitiis in Malebolge. ${ }^{1}$ Furthermore, all the sins of fraud undermine the very foundations of civil society, as Pietro d'Alighieri's gloss to Inferno XI, 52-60 highlights with its references to Aristotle's Politics and to Justinian's code, the Corpus Juris Civilis. ${ }^{2}$ In the last pocket of Malebolge, this is emphasized by the punishment of the falsifiers: for their corruption of the 'body politic' through alchemy, impersonation, counterfeiting (especially of coinage), and lying, they must suffer eternally four horrific diseases: leprosy, insanity, dropsy, and a raging fever.

The social-political dimension of Dante's moral structure is reinforced in the pit of Cocytus (circle 9), where treachery is punished in four sub-circles: Caina (to kin), Antenora (to country), Ptolomea (to guests), and Judecca (to lords and benefactors). In Dante's hierarchy, the first loyalty is to one's lord, the second to 
guests, the third to country, and the fourth to family. Dante thus considers it worse to betray one's lord than to betray members of one's own family. This reflects a key link between Dante's ethical theory and his imperial political philosophy. Where the Florentine state was soon to celebrate the republican Brutus, Dante audaciously counterpoises Brutus and Cassius's betrayal of Julius Caesar with Judas's betrayal of Christ: the three sinners are endlessly chewed in Satan's three mouths. Dante considers Brutus and Cassius the very worst sinners precisely because, betraying their lord, they sought to frustrate the divinely ordained establishment of a universal ruler.

Although Virgil's rationale for the moral structure of Hell delineates the four principal regions of Hell that take up thirty of Inferno's thirty-four cantos, it strikingly leaves out Hell's first section, where the 'neutrals' reside, and which lies inside the infernal gate but outside the circles of Upper Hell (Inf. III), as well as Virgil's own eternal resting-place, the Limbo of the virtuous pagans within the first circle (Inf. IV), and the very area in which Virgil gives his lecture, the sixth circle of heresy (Inf. X-XI). In a literal sense, these three categories are theological not philosophical, they do not concern moral evil as such, and they are not intelligible in pagan or purely rational terms. In an allegorical sense, however, these daringly original regions of Dante's Hell are the exceptions that prove the rule, arguably reinforcing the Aristotelian taxonomy underpinning the moral structure of Hell as a whole. The neutrals, who pursued neither good nor evil, may correspond to Aristotle's category of the pusillanimous: the river Acheron, on this reading, divides sins of omission (Inf. III) from sins of commission (Inf. IV-XXXIV). In the first circle of Hell, the exceptional virtue of the pagans may inversely parallel the exceptional degree of vice of the treacherous souls in the ninth circle (the pit of Cocytus). Aristotle, indeed, counterpoises incontinence with continence, malice with virtue, and extreme malice (or bestiality) with a rare superhuman level of virtue. Furthermore, where heresy is, conventionally at least, a specifically Christian sin, Dante singles out for special treatment the 'Epicureans' who are remarkable for their political and intellectual prowess, and are punished for denying the immortality of the soul rather than for any strictly moral fault.

What motivated Dante explicitly to privilege Aristotle as his primary ethical authority in Hell (in Inferno XI, Virgil directly cites Aristotle's Ethics (80), his Physics (101) and, arguably, his Metaphysics (97) within just twenty-two lines)? After all, as Alison Morgan has shown, most of the sins punished in Dante's Hell are found in popular Christian visions of the other world, or are listed in twelfth- and thirteenth-century confession manuals. ${ }^{3}$ In major part, the cause was Dante's polemical ethical-political programme. Dante believed that the pagan Aristotle had given a comprehensive account of secular ethics, and this justified his insistence that philosophical principles were sufficient to guide humans to this-worldly felicity and to provide the basis for law in the political sphere. But why, in that case, did Dante choose Virgil, the poet of Roman Empire (Inf. I, 73-4), and not Aristotle, 'the master of them that know' ('l maestro di color che sanno; Inf. IV, 131), as his moral guide? In the Convivio, Dante argues that, while imperial power without ethics is dangerous, 
ethics without political power is weak (IV, vi, 17). In Purgatorio VI, Dante bemoans the empty seat of empire: what use are laws if there is no one to enforce them (8890)? Dante believed - against apologists for papal temporal power - that only a restoration of the Holy Roman Empire could lead to the establishment of moral order and therefore peace on earth. Arguably, then, one purpose of Dante's Inferno is to represent in the afterlife the moral justice which, in the absence of an Emperor, Dante saw unfulfilled on earth.

\section{Purgatorio}

In the penultimate canto of Purgatorio, Beatrice glosses an allegorical representation of the Church's moral corruption (XXXII, 100-60). The final vision of the 'whore' (puttana; 149 and 160) almost certainly refers to the papacy of Boniface VIII (12941303), while the detachment of the sacred chariot from the tree represents the transference of the papacy from Rome to Avignon in 1309. In opposition to a decadent Church in Babylonian captivity, Dante's Purgatorio presents a moral vision of the Church fulfilling its true divine mandate to lead sinners back to God. Dante draws on two important developments in the Church's ongoing reform. In response to a renewed emphasis on the practice of confession at the Fourth Lateran Council (1215-16), theologians mined the tradition of the seven capital vices as a convenient scheme for Christian ethical formation. As the doctrine of Purgatory gained more prominence in the life of the Church (it was only given the official stamp at the Second Council of Lyon in 1274), preachers sought to explain purgatorial suffering as, in part, an extension of earthly penance. In depicting the seven terraces of Purgatory (Purg. IX-XXVII), Dante thus fused this popular material on the seven capital vices with the emerging connection between earthly penance and purgatorial suffering. Dante's Purgatory is 'where the human spirit is purged and becomes fit to ascend to Heaven' (dove l'umano spirito si purga / e di salire al ciel diventa degno; Purg. I, 5-6).

There are, then, four key differences between infernal and purgatorial suffering. First, whereas Hell punishes sins or evil actions, Purgatory purifies vices or evil habits. The seven capital vices are 'seven springs' from which 'all the deadly corruptions of souls emanate'. ${ }^{4}$ Second, whereas corporeal suffering is unredemptive in Hell, it has a twofold purpose in Purgatory: according to its intensity, it punishes a sinner's guilt and, according to its duration, it corrects a sinner's vicious dispositions. Third, although all souls not in Paradise experience the lack of the divine vision (poena damni), this deprivation is perpetual in Hell but only temporary in Purgatory. Fourth, whereas evil is punished principally in accordance with natural ethics in Hell, the completely different moral order of Christian holiness emerges in Purgatory: 'here they make themselves holy again' (qui si rifà santa; Purg. XXIII, 66). Dante's treatment of wrath, avarice, gluttony, and lust is essentially different, therefore, in Hell and in Purgatory. For example, gluttony is punished in Hell as the failure of 
reason to moderate the appetite. By contrast, on the mountain of Purgatory (at the exact antipodes of Jerusalem, the place of Christ's crucifixion), the gluttonous souls' extreme fasting - their faces become dark, hollow, and wasted, and their eye sockets like rings without gems (22-33) - leads to spiritual union with Christ (70-5).

The moral structure of Purgatory is only articulated in the central terrace of Purgatory (Purg. XVII), and at the centre of the poem as a whole. Dante-character and Virgil arrive at the fourth terrace of sloth at nightfall and, as the mountain cannot be climbed without the light of the sun (symbolically without the grace of God), they are forced to wait. As in the corresponding episode in Inferno XI, Virgil makes the time profitable by explaining the region's moral structure. Its foundation is the universal relationship of love between the Creator and His creation: 'Neither Creator nor creature [...], my son, was ever without love' (Né creator né creatura mai [...] figliuol, fu sanza amore; XVII, 91-2). Virgil distinguishes, however, between two principal kinds of love: natural love and love of the mind ('naturale o d'animo'; 93). Natural love is shared throughout the order of creation: it is the love that makes any material body fall to the earth, fire to ascend, a plant to grow, or an animal to move towards food. As it is determined, this natural love is always without error. By contrast, rational love ('d'animo'), which specifies humans as 'rational animals', is subject to free will. As elective, this rational love may err, and such disorder is vice. For this reason, love is not only the seed of every human virtue, but also of every human action that deserves punishment (XVIII, 103-5). The function of Christian ethics, then, is the reordering of human love. As Augustine emphasizes, 'a brief and true definition of virtue is "rightly ordered love". That is why, in the holy Song of Songs, Christ's bride, the City of God, sings, "Set charity in order in me", (De civ. Dei, XV, 22). Everything must be loved, including the self, insofar as it is ordered to God.

To describe this disordered love in terms of the seven capital vices, Dante adopts the moral framework provided by the Dominican friar William Peraldus in his treaties on the vices (De vitiis). ${ }^{5}$ Dante divides disordered love into two main categories: love of an evil and perverted love of a good through excess or deficiency (XVII, 94-6). The evil loved must be directed against one's neighbour (106-14), as humans necessarily love their own existence and God as the cause of that existence. Dante defines pride, envy, and anger, therefore, as different ways by which we may hate our neighbour. The proud hope for excellence through the humiliation of others (115-7). The envious fear to lose their power, honour, or fame through the success of others, and thus desire that others be brought low (118-20). The angry, because of some injury, are desirous of revenge and are ready, therefore, to harm their neighbour (121-3). What, then, about the disordered love of the good? The unmeasured love by deficiency ('per poco di vigore'; 96) is the quiddity of sloth: the distinctive failure sufficiently to love God, the greatest good. Unmeasured love by excess ('per troppo [...] di vigore'; 96) is the genus of the three final vices of avarice, gluttony, and lust $(136-9)$.

Virgil's doctrinal lecture may be represented poetically through the figure of the 
siren that appears in the pilgrim's second dream on the mountain (XIX, 1-33). As the opening metaphor of the canticle highlights (I, 1-2), our life is a sea-journey to God. The first triad of vices - pride, envy, and anger - concern internal spiritual blindness that sets us off on the wrong course leading to hatred of neighbour. This internal blindness is corrected on the three corresponding terraces: proud eyes are bent low, envious eyes stitched up, wrathful eyes plunged into impenetrable darkness. The second triad of vices concerns the disordered attraction towards external sensible things: the avaricious seek to possess all they see; the gluttons are possessed by the taste of foods and drinks; the lustful by the touch of sexual pleasure. Given where she appears, the siren arguably embodies a transition from the internal to the external triads of vices: she does not just distract the wayfarer from his true course and entice him to slow his oar (the specific vice of sloth), she seduces him to follow unworthy worldly cares and distractions. Indeed, in classical illustrations of the siren, her closed arms depict avarice; her fish's tail, gluttony; her virginal face, lust.

Dante only uses the noun 'Purgatorio' (VII, 39; IX, 49) to refer to the seven terraces of the mountain (Purg. X-XXVII), and Virgil's lecture just explains the moral structure of this region. As with his corresponding lecture on Hell, Virgil leaves out what are arguably the most theologically original parts of the canticle in terms of moral structure: an antechamber conventionally named Ante-Purgatory that stretches from the shore up a rock face to Purgatory's gateway (Purg. I-VIII), and the Earthly Paradise at the summit of the mountain (Purg. XXVIII-XXXIII). Dante condemns five groups of souls to Ante-Purgatory: the spiritually tardy (who must wait at the mouth of the river Tiber for their ferry crossing to the shores of Purgatory), the excommunicates (Purg. III), the lazy who delayed repentance (Purg. IV), those who repented at the last minute, even at point of death (Purg. V-VI), and negligent rulers (Purg. VII-VIII). According to a novel kind of contrapasso, the souls in Ante-Purgatory - deprived temporarily of the purifying pain of sense (poena sensus) - are forced to experience exclusively the lack of the divine vision (poena damni). There is, in this way, a direct correlation between the souls in Ante-Purgatory and those in Limbo (who also do not suffer the poena sensus). There is also a key difference. The poena damni of the souls in Limbo is eternal: they 'live without hope in desire' (che sanza speme vivemo in disio; Inf. IV, 42), whereas the poena damni of the souls in Ante-Purgatory is temporary: they live, with hope, in desire for the beatific vision. And it is this hope that makes their waiting - for the excommunicates, thirty times the period of their contumacy; for the rest, the period equal to the duration of their earthly lives - bearable.

The emphasis in Ante-Purgatory on those who have delayed their penitence on earth and thus must wait, as a punishment for delaying, for the purifying pain of sense (poena corrigentis) highlights that Purgatory continues a moral process that should have started in this life. Ante-Purgatory is framed by the appearance of four stars symbolizing the cardinal virtues and three stars symbolizing the theological virtues that rise in their place (I, 22-7; VIII, 85-93). The region is characterized by a powerful nostalgia for the world left behind and, on reaching Purgatory, Dante- 
character is warned by the gate-keeper that 'whoever looks back must return outside' (di fuor torna chi 'n dietro si guata; IX, 132). In Augustinian terms, Christians must be in but not of this world: they are pilgrims (peregrin; II, 63) moving through a temporary dwelling place on their way to their true home, the celestial city (De doctrina Christiana, I, 4). In a thinly-veiled allegory at the door of Purgatory (IX, 70-145), Dante-character undergoes the sacrament of penance and, on absolution, enters Purgatory to begin his satisfaction for his sins that are ritually marked as seven Ps (peccata) on his forehead. Through the seven terraces of Purgatory, Dantecharacter is purged of the seven sins and the seven Ps are miraculously erased.

The first terrace is of pride, the worst of the seven sins in the order established by St Gregory the Great. Pride and envy are both vices associated with the intellect and are graver, and thus lower on the mountain, than wrath and sloth (associated with the irascible appetite) and avarice, gluttony and lust (associated with the concupiscible appetite). The seven sins are, moreover, causally connected: thus pride begets envy as, in seeking an empty renown, the soul feels envy towards someone able to obtain it; the last vice, lust, may be caused by gluttony as the inordinate consumption of food may dispose the soul to sexual wantonness. Dante draws out different aspects of a given vice establishing, for example, a threefold division of pride in relation to time: Omberto Aldobrandeschi took pride in his ancestors (XI, 58-72); Provenzan Salvani in his present political power (109-42), and Oderisi in his future artistic fame (82-108). In keeping with popular tradition, Dante pairs each of the seven capital vices with one remedial virtue: thus pride with humility (Purg. XXII), envy with charity (XIII-XV), wrath with gentleness (XV-XVII), sloth with zeal (XVII-XIX), avarice with poverty (XIX-XXII), gluttony with abstinence (XXII$\mathrm{XXV}$ ), and lust with chastity (XXV-XVII). These abstract vices and virtues are embodied in the vicious and virtuous actions of particular individuals in episodes taken from the Bible, from pagan myth, and from history. The narrative exempla are presented in contrasting ways from sculptured reliefs (humility and pride) and ecstatic visions (gentleness and wrath) to disembodied voices (envy and charity). The Virgin Mary occupies the most important role as the model par excellence of the path to Christian virtue, and prayerful meditation upon her life is presented as a remedy for the wounds of sin. The souls in Purgatory are also orientated to God through passages of Scripture, the beatitudes, liturgy, and major Christian prayers.

Where the pains of Purgatory as a whole were conventionally depicted as a refining fire, Dante specifically reserves fire for the seventh terrace. This has two advantages. First, Dante effectively evokes through fire the intense burning of sexual desire, whether natural (heterosexual), but potentially bordering on the bestial, or against nature (same-sex). Second, Dante brings together the final suffering of Purgatory with 'the fiery revolving sword' which guarded Eden after the Fall (Gen. 3:24) equating, thereby, the restoration of grace after ritual purgation with the recovery of a restored Earthly Paradise. However, Dante's syncretism is even more daring as he explicitly identifies Eden with 'the golden age and its happy state' dreamed by the pagan poets (l'età de l'oro e suo stato felice; XXVIII, 139-41). 
Strikingly, it is at this stage that Virgil nonetheless departs the scene. As is clear from the encounter with Statius (Purg. XXI-XXII), Dante conventionally believed that Virgil's fourth eclogue had prophesized Christ without the poet's awareness, so that Virgil himself had not benefitted from its miraculous intuition. Although Virgil crowns Dante-character at Purgatory's summit with a will which is free, upright, and healthy (XXVII, 124-42), his role of guide is overtaken in Eden, first by Matelda and then, after a procession which allegorizes God's revelation through the books of the Bible, by Beatrice. The moral climax of Purgatorio is Dante-character's encounter with Beatrice, who is circled by handmaidens representing the three theological and four cardinal virtues. The pilgrim is forced to confess his sin in turning from her before having the memory of his sins washed away in the river Lethe and his good memories restored in the river Eünoè. Only then, and in the last line of Purgatorio, is the pilgrim finally 'pure and made ready to rise to the stars' (puro e disposto a salire a le stelle; XXX, 145).

\section{Paradiso}

With Inferno and Purgatorio, Dante combines moral schemes within invented topographies: the subterranean funnel of Hell in the northern hemisphere and the seven terraces of Mount Purgatory in the southern hemisphere. With Paradiso, by contrast, Dante starts with the actual universe as perceived in early fourteenth-century Ptolemaic astronomy: the seven planetary spheres, the eighth sphere of the fixed starts, the primum mobile, and the Empyrean. Dante informs us, however, that the souls in Paradise actually reside only in the Empyrean, the highest of the ten regions described. The blessed souls appear in the other celestial spheres just for Dantecharacter's benefit: in order to signify to him their different grades of beatitude (Par. IV , 28-39). As Scripture condescends to human faculties in attributing feet and hands to God, but means otherwise, so the blessed souls thereby condescend to Dantecharacter's human mode of knowing: from sense perception to intellectual cognition (IV, 40-8). There is in Dante's Paradiso, then, a clear distinction between what Paradise is (the ontological status of the blessed souls in the Empyrean) and how Paradise is conveyed (the illustrative appearance of the blessed souls and the angels in the nine celestial spheres). This distinction seems particularly appropriate to Paradiso, with Dante's insistent emphases on the limits of the human mind to comprehend divine realities and the even more limited capacity of human language to express them.

The simultaneous unity and diversity of the blessed souls - sharing the beatific vision but in different degrees - raises, however, a pressing theological question: how are degrees of beatitude compatible with the perfection of Paradise? Notably, the blessed soul to whom Dante-character addresses this question is Piccarda Donati. In Purgatory, Dante-character had asked her brother, Forese, 'where is Piccarda?' (dov'è Piccarda; Purg. XXIV, 10), only to be informed that she 'triumphs joyous with her 
crown on high Olympus' (trïumfa lieta / ne l'alto Olimpo già di sua corona; 14-15). In the same encounter, Forese had prophesized the death and damnation of their brother, Corso, whom he foresees dragged 'towards the valley where guilt is never forgiven' (inver' la valle ove mai non si scolpa; 84). The hierarchy of Paradise is thus related to the central issue of divine justice in Dante's moral vision as a whole. Infernal pain, purgatorial suffering, and paradisiacal bliss are of different degrees in the afterlife because human beings are not equal in merit or fault on earth. But, as Piccarda explains, a lower degree of bliss in Heaven does not imply a lack of perfection because God's favour is proportionate to a particular individual's capacity to receive it. Repeating the word 'more' (più) thrice in two lines (Par. III, 65-6), Dante-character asks Piccarda, the 'least' of the blessed, if she desires a higher place. Smiling 'a little' (un poco; 67), Piccarda explains that were she to desire 'more' (più; 73) her will would be discordant with God's will: to be in God's will is the peace of Paradise (64-87). The pilgrim understands, thereby, both that everywhere in Heaven is Paradise and that the grace of the highest good does not rain there in equal measure (88-90).

How, then, does Dante structure the celestial spheres to represent these different degrees of beatitude? In the Convivio, Dante had already used the Ptolemaic heavens to project his idea of the system of knowledge (II, xiii, 2-20), playfully connecting each discipline with a heaven by a shared characteristic: for example, the ninth sphere of the primum mobile, which sets the eight lower celestial spheres spinning in their diurnal rotation, is like ethics, which orders our learning of all the other branches of knowledge (14-18). For Paradiso, however, Dante rejects any straightforward analogy of this kind. Instead, alongside any symbolic significance, he insists upon the material effect of each of the heavenly spheres on the sublunar world. The discourses on free will at the centre of Purgatorio clarify that, for Dante, only the human intellect, as non-material, is free from astral influence (XVI, 67-130; XVIII, 49-75). All the human bodily organs and faculties including imagination, judgement, personality, and artistic gifts are influenced by the seven planetary heavens, an influence Dante considered to be more powerful than heredity.

As Charles Martel highlights (Par. VIII, 94-148), it is through these astral influences that Providence brings about the diversity in natural gifts necessary for society. Ascending through the seven planetary heavens, Dante encounters groups of souls, therefore, whose lives and missions were directly informed by the particular influences of the planetary sphere in which they appear. When we find lovers in the sphere of Venus, this is because Dante believed that the planet literally moved or disposed people under its influence to love. It is equally true, nonetheless, that the seven planetary heavens would have suggested to Dante the ethical schemes of the seven remedial virtues or the three theological and four cardinal virtues. As we have seen, the former scheme is adopted in the seven terraces of Purgatory, while the latter is anticipated by the stars in Ante-Purgatory and Beatrice's handmaidens in Eden. For his vision of Paradise, the poet overlaps the scheme of the cardinal and theological virtues with the idea of astral influence on personality. 
As the sun is the fourth planet orbiting the earth in geocentric astronomy, it was believed that the earth's shadow partly obscured the first three planets. Dante uses this 'shadowed' aspect of the heavens of the Moon (Par. II-V), Mercury (VVII), and Venus (VIII-IX) to represent the three theological virtues - faith, hope, and love - tainted by earthly concerns. The equation between faith and the inconstant in vows (Moon), between hope and the glorious in earthly fame (Mercury), and between charity and the earthly lovers (Venus) is, however, no more than implicit. In fact, some scholars have interpreted these spheres in terms respectively of imperfect fortitude, justice, and temperance. Both interpretations are plausible. Piccarda was inconstant in her vow when seized from her cloister unlike, she says, St Clare of Assisi who persisted in her pledge of consecration despite threats (III, 98-9). Not holding to her vow even unto martyrdom, Piccarda thereby lacked both faith and fortitude. Justinian pursued justice on earth and consequently is presented as the ideal of the emperor-ruler. Yet he was overly motivated by the hope of earthly fame rather than by hope of eternal glory. Cunizza was compassionate in later life, and yet infamous for her serial lovers and marriages. Her love was intemperate and fell short of the perfect love of charity.

There is little doubt about the relationship between the next four planetary spheres and the four cardinal virtues. Prudence is clearly associated with the Christian intellectuals in the heaven of the Sun (Par. X-XIV), fortitude with the Christian crusader-martyrs in the heaven of Mars (XIV-XVII), justice with the just in the heaven of Jupiter (XVIII-XX), and temperance with the contemplatives in the heaven of Saturn (XXI-XXII). Yet, the scheme of the cardinal virtues is still subordinated to the primary consideration of astral influence. Thus, following Aquinas, it might have been more natural for Dante to pair prudence with temperance and justice with fortitude, as we need temperance to follow what prudence counsels, and fortitude to fulfil the social demands of justice. But Dante pairs prudence with fortitude and justice with temperance, and this is because - in terms of planetary influence - the human disposition to temperance is associated with the cold planet Saturn, while the virtue of fortitude is associated with the fiery planet Mars. Beyond the seven planetary spheres (II-XXII), the theological virtues reappear in the eighth heaven of the fixed stars, where saints Peter, James, and John become the shining exempla of faith, hope, and charity (XXIII-XXVII), and Dante-character is examined by them on each of these virtues in turn.

Although it is possible to draw out the moral structure of Dante's Paradise in this way, there is no parallel in the canticle to Virgil's lessons on the moral order of Hell and Purgatory. There is, however, a backward glance at the seven planetary spheres in Paradiso XXII, 133-5 and 151. This detached, contemplative perspective on the world (in the tradition of the contemptus mundi) is ethically significant, because it is exactly what Dante believed was lacking in his own time, and particularly so in the Roman Church. The origins of the papacy in St Peter, of western monasticism in St Benedict, and of the mendicant orders in St Francis were all characterized by material poverty (88-93). But, where the Church Fathers searched 
for God, the slothful modern prelates desire only riches and worldly power: they have taken Cupidity not Poverty as their wife (Ep. XI. 14-6), and their 'avarice afflicts the world, trampling the good and raising up the wicked' (la vostra avarizia il mondo attrista, / calcando i buoni e sollevando i pravi; Inf. XIX, 104). Dante's condemnation of the contemporary papacy reaches its climax in Peter's denunciation of his current successors: in the eyes of the Son of God, the seat of the papacy is vacant, and his burial place has become a sewer (Par. XXVII, 22-7).

An overarching moral theme of Dante's Paradiso, then, is Christian asceticism and the Church's true mission to lead people to God. In the first, fourth, and seventh of the planetary spheres, Dante places especial emphasis on religious orders and the religious life. Piccarda and Costanza were Franciscan nuns, 'Poor Clares', before being violently abducted from their cloister. Thomas Aquinas and Bonaventure praise the founders of each other's orders, St Dominic and St Francis, while denouncing the subsequent degeneracy of their own. St Benedict, the founder of western monastic orders, and St Peter Damian, a rigorous reformer, extol the ascetic contemplative life. Alongside a moral critique of the contemporary Church, Dante's Paradiso also provides an ideal model for the Empire and its relationship to the Church. In the second sphere of Mercury, Dante upholds Justinian as an exemplary emperor who reformed the civil law, he locates the corruption of the papacy in the donation of Constantine, and he lauds pope Agapetus's spiritual counsel of Justinian. In the sixth sphere of Jupiter, the dramatic appearance of Ripheus and Trajan in the eye of the eagle highlights Dante's belief in the providential role of the Roman Empire to administer justice. The heaven of Mars, moreover, celebrates the cooperation of the pope and emperor in the liberation of the Holy Lands through the crusades, with Dante presenting his ancestor Cacciaguida as a de facto Christian martyr. The glorious lives of the souls in Dante's Paradise not only illustrate particular aspects of virtue, therefore, but also provide models for the two institutions of Church and Empire, the 'the two suns' that, for Dante, should make visible 'the two paths, of the world and of God' (due soli [...], che l'una e l'altra strada / facean vedere, e del mondo e di Deo; Purg. XVI, 107-8).

Given the sophisticated organization of evil in Hell, the school of ordered and disordered love in Purgatory, and the joyful celebration of human talents and virtues in Paradise, it is easy to lose sight of the binary division in Dante's moral universe which, from a Christian point of view, is the sole one that ultimately matters, namely, the division between those who are able and freely will to submit themselves to God's infinite love and mercy and those who, wilfully or not, are closed to God's love. The first category includes all those in Paradise and in Purgatory. The second category comprises all those in Hell. The primary condition of souls in Hell, after all, is not only the lack of the beatific vision but, crucially, the lack of any hope that they may ever attain it: on entering Hell's gate, they leave all hope behind (Inf. III, 9). In Purgatory, the souls are joyful - even in suffering - because of their living hope for 
the beatific vision. In Paradise, they enjoy this vision: 'light intellectual full of love, love of true good full of joy, joy that surpasses every sweetness' (luce intelletüal, piena d'amore; / amore di vero ben, pien di letizia; / letizia che trascende ogne dolzore; Par. XXX, 40-2).

This ultimate division between the damned and the saved strongly reaffirms the moral urgency of Dante's poem, written 'for the good of the world that lives badly' (in pro del mondo che mal vive; Purg. XXXII, 103), for those who live and, while alive, still have hope. As Manfred beautifully articulates in Ante-Purgatory, 'none is so lost that the eternal love cannot return while hope keeps any of it green' (non si perde / che non possa tornar l'etterno Amore, / mentre che la speranza ha fior del verde; III, 133-5). The poem's most powerful moral message, then, is God's love for those who turn to Him. As Manfred, smiling, confesses: 'Horrible were my sins, but the infinite goodness has arms so wide that it receives whoever turns to it' (Orribil furon li peccati miei; / ma la Bontà infinita ha sì gran braccia, / che prende ciò che si rivolge a lei; 121-3). Union with God is the fulfilment of all human desires as Piccarda, the first soul encountered in Paradise, explains: 'And in His will is our peace' (E 'n la sua volontade è nostra pace; Par. III, 85-7).

\section{Notes}

${ }^{1}$ Z. G. Barański, Language as Sin and Salvation: A 'Lectura' of 'Inferno' 18 (Binghamton, NY: CMRS, 2014), pp. 36-7, n. 46.

${ }^{2}$ Pietro Alighieri, Comentum super poema Comedie Dantis, ed. M. Chiamenti (Tempe: ACMRS, 2002), gloss to Inf. XI, 52-60.

${ }^{3}$ A. Morgan, Dante and the Medieval Other World (Cambridge University Press, 1990), pp. 10843.

${ }^{4}$ Peter Lombard, The Sentences, trans. G. Silano (Toronto: PIMS, 2008), II, d. 42, c. 6 (p. 210).

${ }^{5}$ S. Wenzel, 'Dante's rationale for the Seven Deadly Sins (Purgatorio XVII)', MLR, 60 (1965), 529-33. 